\title{
12. Multilevel polycentric governance in urban development policies - national urban policy structure in Slovakia
}

Maroš Finka and Milan Husár

\section{INTRODUCTION}

Nearly 20 years of Slovakia's European Union (EU) membership have been significant in multiple and complex economic and social transformation processes influencing the country's urban development. The dynamics of these processes have differed across all hierarchical levels from the local level through to regional and national ones, as well as across both different spheres of social life and different structures of urban social ecosystems. This process has brought, in addition to high pressure on formal decentralisation of competences among different levels of the territorial government system, a reasonably high level of territorial system management disintegration based on sectoral division (OECD 2005). Nevertheless, the complexity of urban development phenomena and the demand for a prompt response to the current challenges displays the need for more integrative approaches and proper formal and informal tools. The goal is to overcome the gaps between:

- managerial and technical responsibilities for solutions and decision-making power over resources;

- fragmented territorial government organisation and cumulation of problems in specific territories;

- political and professional views; and

- sector-specific and territorially comprehensive approaches.

The process of seeking proper responses has not been a challenge unique to Slovakia: contradictory inputs from the EU level, for example through sector-based policy determinations from the European Commission (EC) and directives on the European Regional Development Fund (ERDF), were of little help in establishing comprehensive urban policies. Under such premises, the concept of multilevel polycentric governance, which outlines new approaches 
for integrative and integrated urban policies, has been selected and reflected in two essential documents that establish the principles of the new urban policy in Slovakia: the policy document 'Urban Development Policy of the Slovak Republic by 2030' (Koncepcia mestského rozvoja Slovenskej Republiky do roku 2030) and the report on the fulfilment of the intentions of the Concept of the State Housing Policy until 2020 (Ministry of Transportation and Construction of the Slovak Republic 2018a; 2018b).

\section{DEVELOPMENT OF SETTLEMENT SYSTEM AND CURRENT CHALLENGES FOR TERRITORIAL GOVERNANCE DEVELOPMENT}

In 1950, Slovakia, with just 26.2 per cent of its citizens living in towns, was a rural country with a low degree of urbanisation. Development from the 1960s to the 1980s was characterised by a considerable lag of qualitative changes in the structures of settlements compared to quantitative changes, due to respecting neither natural nor cultural features of the regions and settlements. The concentration of production and job opportunities in cities and towns was the primary factor in forming the settlement system in Slovakia, where at the same time the concentration of job opportunities had vastly overtaken the qualitative development of the environment in the settlement units, including the development of housing and services. The planned management of settlement structure development, with its proclaimed objective of achieving social equality, was implemented in a distorted way, missing out systematic relations and forcing development to the detriment of sustainability of the economic and environmental quality of the societal development. As environmental and economic aspects, which are essential components of the social dimension for an adequate living standard, were ignored, social equity goals could in no way have been reached by this approach.

As late as the end of the 1960s, 60 per cent of job opportunities were located in urban settlements, even though only 30 per cent of the total population was living there. By the 1980 s, only 25 per cent of job opportunities were to be found in rural settlements, despite the fact that 43 per cent of the total population was living there. Therefore, of all economically active people, only 53.8 per cent were able to find a job within their place of residence while the remaining 46.2 per cent commuted (Finka 2002).

This proportion gradually equalised, but even as late as the end of the 1980s, in some agglomerations job opportunities not bound to the locally disposable workforce still accounted for more than half of all job opportunities.

This development determined the establishment of strong agglomerative relations of settlement centres represented by cities and their environments, as well as the diffusion of urban ways of life into rural areas. These trends con- 
tinue today and have resulted in a considerable weakening of suburbanisation and deurbanisation trends and their spatial and structural attributes typical of a settlement structure in developed countries.

The basic urbanisation rate expressed by the share of population living in municipalities with more than 5000 inhabitants increased from 26.2 per cent to 56.1 per cent between 1950 and 1991. This development was accompanied by a delay in social and technical infrastructure, a lagging quality of the environment and a rise in demand for residential places in the cities. There were 307 dwelling units per 1000 citizens in Slovakia in 1990, whereas in the developed European countries there were 420 to 460 . The erroneous interpretation of the social equity concept was projected through the unification of housing areas, not respecting the individual needs or particular demands of citizens. The social equity idea was not fulfilled by the centrally planned socialist society either in terms of quantitative parameters or in terms of qualitative ones. This situation has not changed much in the last decades, and the performance of Slovakia in the provision of houses was ranked 25th among OECD member states in 2015, lacking approximately 200000 dwelling units and displaying a very uneven distribution across the country (Ministry of Transportation and Construction of the Slovak Republic 2018a). Moreover, the most recent development has brought on a rather intensive process of suburbanisation, with a decrease in the number of inhabitants in the core cities as well as in rural areas outside agglomerations and a rise in inhabitants in the urban agglomeration areas outside their core cities. The disparities between this development and the adjustment of technical, transport and social infrastructure represents one of the biggest challenges for urban development policies.

A stable share of the Slovak population (more than 20 per cent) lives where most of the economic activities are concentrated: in the western part of Slovakia belonging to the Central European metropolitan region with the core agglomeration Vienna-Bratislava. Bratislava is a self-governing region, being the agglomeration core in the heart of this metropolitan area, and belongs to the wealthiest regions in the EU based on GDP per capita, which is a relevant, attractive feature for the further concentration of people and activities. There exists a large core-periphery division in Slovakia in terms of private and public research and innovation and institutional capacities - Bratislava's GDP is 2.4 times higher than the average for Slovakia and is home to 53 per cent of the country's research capacity (research staff and facilities; Schulz 2019). The objective of the EU Cohesion Policy was to decrease the gap in productivity and welfare as well as foster growth in a way that also supports territorial cohesion between regions (Iammarino et al. 2017). However, several studies support the claim that the Cohesion Policy in Central and Eastern Europe never improved territorial cohesion and de facto only exacerbated regional disparities (Faragó and Varró 2016; Lang and Görmar 2019). 
Tension in the housing market, lack of development of public infrastructure including social and transport infrastructure, and the precarious economic situation of the population are negatively reflected in citizen mobility, even though these factors have a stabilising influence concerning the settlement structure (Jaššo and Petriková 2016). However, as a consequence of migration towards the principal agglomerations there is pressure on the government to change the current way in which the population is spread over the country. Also, immigrants from abroad will gravitate to these centres. Therefore, it is likely that the disparities in population development in specific municipalities and regions of Slovakia will increase.

The absence of an economically stronger middle class and a relative abundance of areas with development potential for individual housing in the medium-sized cities slowed down the process of deurbanisation in a significant way. At the same time, it facilitated the process of suburbanisation in agglomerations. Site and location factors also come into play when it comes to investments creating new job opportunities. Still, the change in value systems of the population in the context of social transformation determines the balance of the impact of this transformation on human and environmental aspects.

In Slovakia, specific developments that have occurred recently can be depicted as selective re-urbanisation. The dynamics of population growth can slow down rapidly, and this slowdown is mainly related to a decreasing turnover of the urban population. Changes in population value systems, along with the changing economic and environmental conditions, make city centres more attractive, primarily the centres of supra-regional and international significance and the urban settlements within their agglomerations. This development has been reflected in the halting of the rapid decrease in the number of small municipalities with up to 5000 inhabitants and in the increase in the number of cities with over 20000 inhabitants. With the overall stabilisation of the population numbers, the increase in cities of over 20000 citizens has been minimised, the decrease in the number of municipalities of between 10000 and 20000 citizens has been stopped, and the population in the municipalities of between 500 and 10000 citizens has increased slightly. The process of suburbanisation in the metropolitan region of Bratislava has been driven by European integration, in the context of which, in 2007, the state borders creating the borders of Bratislava, which lies at the triangle of the Slovak, Austrian and Hungarian borders, became Schengen borders. The gap between the very high real estate prices in Bratislava (comparable with the prices in some core districts in Vienna) and prices in neighbouring municipalities in Hungary and Austria, together with their well-developed transport connections to Bratislava, generated the flow of migration from the city towards rural municipalities in the Hungarian and Austrian parts of the Vienna-Bratislava agglomeration. 
For the past two decades, the development of urban structure in the Slovak Republic has primarily been influenced by the processes of transformation from an industrial to a post-industrial society. Currently, it is being influenced by a transformation towards Industry 4.0, directly impacting on more than 45 per cent of workplaces in the national economy, which is dominated by the automotive industry (Zajko and Brighton 2015). There is a change in the nature of the configuration of the vital economic sources and their accessibility. These sources are now represented by knowledge and information and their distribution is not bound to the physical structures and location characteristics of the source and the user. It means that accessibility to the key sources of economic development is not location dependent but relies on the development of appropriate infrastructure and literacy, directly bound to implementing deliberative planning activities, either sectoral or cross-sectoral.

Apart from loosening the spatial relationships, these processes give rise to the new temporal and spatial structures that direct the rhythm of life in the settlements. These new temporal and spatial structures change the conditions of accessibility not only with regard to employment opportunities and educational and recreational facilities but also with regard to social and other services. The different efficacy and availability of these activities is much less dependent on technological parameters than on organisational and operational parameters that are influenced mainly by effective activity planning. This has been clearly shown during the COVID-19 crisis, where organisational interventions allowed the flexible temporal functional transformation of service infrastructure to cover specific demands and to make selected services accessible even given the limited mobility of citizens.

With the changing profile of the labour force towards higher flexibility, the conditions of following a career in the labour market shift as well. On the one hand, it loses its spatial ties, while bringing the threat of exclusion of precarious social groups. An increase in productivity means an inevitable reduction in working time and thus a decrease in the required capacity of the labour force. Greater flexibility in the labour force brings in new requirements for recreational activities and the quality of the housing environment. Nevertheless, it means the diminishing of disposable job opportunities, particularly in terms of poorly educated groups of a lower social status, which can, without a deliberate planning intervention, lead to the social degradation of some settled areas.

\section{TERRITORIAL GOVERNANCE AT LOCAL AND REGIONAL LEVEL AND URBAN POLICIES}

The administrative structure of the Slovak Republic consists of a polycentric network of 141 cities and 2749 rural municipalities. Only ten cities have more than 50000 inhabitants. Of the 2890 municipalities in total, more than 65 per 
cent are municipalities with fewer than 1000 inhabitants, representing only around 16 per cent of the total population of Slovakia (Statistical Office of the Slovak Republic 2020). Statistically speaking, based on the number of inhabitants living in municipalities with the official status of cities, Slovakia is a rural country, although the majority of inhabitants live in cities and towns in urban agglomerations and their way of life is urban and work-oriented, using services and spending the majority of their lifetime in an urban environment. This is in contradiction with the common definition adopted by the European Commission and the OECD in 2011 for the purpose of comparing cities. In this definition, a city is defined by density values, population size and a link to the political level (i.e. a form of local self-government). In terms of density, at least 50 per cent of the population must live in an urban centre (defined by density and a minimum number of 50000 inhabitants) and at least 75 per cent of the population of the urban centre lives in a city (which usually is the case when the city is a municipality) (Dijkstra and Poelman 2012). Based on this definition, there are only ten cities in Slovakia.

According to current legislation, it is possible to declare a municipality a city or a town even if the settlement has fewer than 5000 inhabitants, as long as it is an economic, administrative and cultural or tourism centre (or spa area), it provides services for the inhabitants of the surrounding municipalities, it has a secured transport connection with the surrounding municipalities, and at least a part of the built-up area within the territory is of urban character (Act no. 369/1990 Coll.).

With the introduction of directly elected bodies of local self-government in 1990, a dual model of public territorial administration comprising state bodies and self-governmental bodies at the local level started to be implemented in Slovakia. Despite remarkable progress in the democratisation of public administration and the handing over of a considerable part of competencies and responsibilities for properties and public finances to local governments, a somewhat centralised model of public administration persisted in the period of 1990-2001. Although eight regions and 79 districts were established as an intermediate tier of subnational government by the 1996 Act on Territorial and Administrative Division (SR No. 221/1996), the introduction of new concepts of decentralisation and modernisation of public administration was delayed until 2001 when the dictum of the Slovak Constitution was fulfilled by adopting the Act on Self-Government of Regions (SR No. 302/2001). This opened the way to the establishment of another level of territorial governance in the form of self-governmental regions and the election of regional parliaments in 2002. This wave of decentralisation led to the transfer of more than 300 competencies from the state administration to the municipalities and regions, not only strengthening the system of representative democracy but also creating new and improved conditions for direct democracy as well, especially in 
terms of participation of the public and private (entrepreneurial, civic) sector in decision-making at the level of cities, municipalities and regions. With Act 416/2001 on decentralisation and transition of competences from state government bodies to self-government bodies at regional and local level, key competencies in spatial development, including those concerning urban issues, have been shifted to the respective self-governing bodies.

Even though the objectives of decentralisation and delegation of power have been achieved, for example through the shift of competences from the national to the regional and local level, disparities still persist. In fact, the presence of numerous imbalances between the responsibilities and competencies shared by state and self-government bodies impacts the efficiency, flexibility and rationality of the whole public administrative system. The problem represents a considerable fragmentation of self-governing units at the local level, with 2890 municipalities and a high heterogeneity within the eight self-governing regions not appropriately equipped with competencies, financial resources and structures for inter-communal coordination. By contrast, there is the state governmental system with its dominance of sector approaches, supported in its sectorality by EU policies. This silo approach is significant and leads to rather inefficient integration and territorial coordination of sectoral policies, exacerbated by the territorial division of administrative districts not corresponding with self-governmental structures at the regional level. Fragmentation is increased by the division of responsibilities for rural, urban, regional and territorial development among three different bodies of central government and the dominant role of the tax income redistribution system at the state level. With regard to the governance of urban development, the public sector communicates insufficiently and often only formally with the private sector.

The change in attitudes towards developing efficient governance mechanisms built on the principles of multilevel polycentric governance is gradual and particularly concentrated in those localities where civic society is well organised in non-governmental organisations (NGOs) comprising professional organisations and initiatives. It applies especially in urban areas and in areas with higher educated populations. The increased responsibility of the local councils also accentuates the need for changes in communication among the public authorities, citizens and the private sector.

Classical methods of communication with citizens are going to be augmented with new effective forms of public participation in the management of public issues - public participation in formulating the visions, principles and goals for city development, definition of programmes, projects and measures through public meetings, involving people in the dialogues around particular planning and programming documents, discussion groups (e.g. implementation of the Urban Development Agenda 2030, see below), and recently, more and more in looking for practical solutions facing the problems of critical 
resource management, climate change effects mitigation or crisis management during the COVID-19 crisis.

The model of public administration in the Slovak Republic assumes territorial sovereignty and subsidiarity across two levels of self-governmental bodies and accordance between the authorities responsible for the management of the territory and the planning documents at the local and regional level. It conversely means decision-making sovereignty for municipalities and the right to procure land and approve land-use plans and structural plans for their territories. However, they can't act in contradiction to the decisions and territorial development plans approved at the regional level. Governance of urban development follows the objective of sustainability and an increase in the quality of life of people. An increase in the quality of urban life requires an increase in the quality of the environment, as well as the growth of the urban economy and the development of technical and social infrastructure.

\subsection{Instruments for Urban Governance}

Good governance of the city and the right political decisions need to be followed up by well-prepared and broadly accepted plans of a high professional quality and, at the same time, a broad public involvement. There is a need for continual, complex and updated information for assessing indicators of urban life quality and for submitting alternative solutions for the development of different spheres of urban life. Municipalities in Slovakia dispose of several instruments for governing urban development and increasing the quality of life of their citizens. These include planning instruments (regulation and development of territory), economic instruments (taxes, financial tools), enactment of norms (generally binding municipal by-laws related to their tasks) and human resources (selection of qualified staff, the election of mayors and councillors).

Planning instruments create two types of integrative, but not well-interlinked, planning systems:

- Land-use planning with the dominance of indicative territorial planning documents at the national (Spatial Development Perspective of Slovakia), regional, local and sub-local level (territorial/land-use plans/zoning) as mid- to long-term instruments of regulation of territorial development, having the character of generally binding documents;

- Strategic socio-economic development planning with its economic planning instruments related to spatial and urban development in the hands of state government (National Regional Development Strategy) and regional and local self-governments (Programmes of Social and Economic Development of regions, groups of municipalities and munici- 
palities) as short- to mid-term instruments with rather weak binding effects (Ondrejička and Finka 2016).

Each planning decision, either in the system of strategic socio-economic development planning or the system of land-use planning, is a political decision, even though its background is usually a professional concept.

Multiple sectoral planning activities complement these two systems (e.g. environmental and landscape planning, health care policy, educational policy, waste management planning, transport planning) covering different fields of responsibilities on different levels of the state-government and self-government bodies. These activities are - in theory - coordinated by land-use planning and strategic socio-economic development planning, but the level of autonomy in relation to these activities is relatively high.

For the governance of local development, municipalities can issue generally binding municipal by-laws which regulate social relations at the local level. These by-laws are binding for all physical and legal entities that permanently or temporarily settle in the municipality. An important instrument of urban governance is its sovereignty. Each municipality can define its organisational structure independently and employ staff using its own criteria.

The real decision-making power of self-governing territorial bodies in relation to urban development in Slovakia depends on the economic power of particular cities. There are significant differences in the level of economic, social and environmental development among regions, cities and municipalities of Slovakia (OECD 2019), and thus the degree of decision-making autonomy of cities and municipalities, as determined by the availability of their own resources, also differs. This can be seen from the data from recent decades showing that more than 95 per cent of total public investment in the state has been financed from EU structural and investment funds where the priorities have been defined by the EU and the national government and only seldom by local governments.

From the viewpoint of the governance of local development, the limiting criterion is the size and population structure of municipalities suffering from a high level of fragmentation as stated above. Due to the recent establishment of polycentric governance structures that are based on shared and delegated competences of newly established inter-communal coordination and cooperation, there are many challenges that affect municipalities. These challenges relate to limited financial resources as well as to constraints in finding professional experts on management who are able to lay the basis for decision-making processes that require inter-municipal participation. This is important in a context that is characterised by the territorial dispersion of urban society in regional systems. Achieving the objectives of urban development 
policies cannot be bound predominantly to the municipal level but is a subject of integrated and integrative policies at the regional level.

\section{URBAN DEVELOPMENT POLICY OF THE SLOVAK REPUBLIC BY 2030 AS AN INSTRUMENT OF MULTILEVEL POLYCENTRIC GOVERNANCE}

The two-year-long process of the formulation of national urban development policy, with the participation of representatives of the city and municipality associations, professionals from public administration, experts and non-governmental organisations, involved intensive work within several thematic working groups, and discussions in cities and regions across the whole of Slovakia as well as consultations with ministries and other public bodies. The arrangement of proper institutional structures for the implementation of the above-described framework was broadly discussed. At the centre of this discussion was the horizontal and vertical division of responsibilities and the potential of the institutional system to act efficiently in reacting to identified problems and challenges. During this debate, the need for a transition from government to governance became clear. Similarly to the debates at the European level, where governance is one of the main keys to succeeding in the process of European integration (Committee of Regions 2020), an increasingly active role of particular municipalities, cities and regions in the process of settlement development and implementation of urban development policies can be seen. At the same time, the ongoing process of decentralisation in Central and Eastern Europe brings an imbalance between their responsibilities, competencies, available resources and capacities as well as a lack of coordination between them and between different levels of policy implementation. This problem is underlined by their exposure to the intercommunal, interregional and international competition as well as an increasing regional polarisation (Lang 2015). An immediate response to this situation is an attempt to reflect major changes in governance in the European Union, where not only has the system started to become a multilevel one with different decision-making centres at different levels (Hooghe and Marks 2003), but there is an increasing tendency to invite representatives from outside the hierarchical administrative arrangement to participate in decision-making (Jordan 2008; Rosenau 1997).

There are many definitions of multilevel governance, but what the majority of them have in common is that they describe processes of the reallocation of authority away from central states (Schakel 2016), that is, better coordination between the hierarchical, top-down levels and the sectoral, problem-oriented jurisdictions. This is done in order to foster transparent, open and inclusive policymaking processes, policy efficiency and policy coherence, and in order 
to promote participation and partnership and budget synergies, as well as to respect subsidiarity and proportionality in policymaking and ensure the maximum protection of fundamental rights across all levels of governance (Committee of Regions 2014). Multilevel governance is characterised by flexibility and adaptability (Ostrom, Tiebout and Warren 1961), self-organisation, spontaneous development and experimentation (McGinnis 1999) and dealing with fuzziness, that is, managing the increased mobility of citizens and their territorial 'sense of belonging' (Finka et al. 2015). Territorial sense of belonging signifies a new dimension to the term 'belonging' concerning the shift from the local to the supra-local and regional level, and even decreases the role of territorial belonging in favour of factually belonging. The diversity of reference qualities for the definition of territorial 'belonging' leads to the overlap of reference spaces. Growing interdependences across territorial unit borders (municipalities, regions, national states) come up against traditional territorial sovereignty (Finka and Kluvánková 2015).

The Urban Development Policy of the Slovak Republic (UDP SR) by 2030 is the first national conceptual document that directly addresses urban development matters in this regard. This document was prepared by the Ministry of Transport and Construction of the Slovak Republic as the responsible central state administration body and adopted by Government Resolution no. 5/2018 of 10 January 2018. By adopting the UDP SR, the Government of the Slovak Republic has committed to the development of cities playing a significant role in the economy and societal development and to promoting sustainable urban development by introducing a set of specific measures as defined in this policy document.

The priority tasks defined in this document cover two main areas in which it is necessary to apply systemic changes: cooperation and coordination among various actors and levels and structural changes with reference to pressing challenges such as data availability, environmental protection, urban mobility and funding.

The progress in implementation will be monitored and regularly reported to the Ministry of Transport and Construction, the Government of the Slovak Republic and, above all, to the stakeholders - the members of the Platform for Development of Slovak Cities and Towns initiated by this Ministry (made up of representatives of cities, experts, professionals from public administration, academia, NGOs and citizens' representatives). Along with this, specialised studies will be conducted, public events organised and general publicity ensured.

The implementation of the UDP SR as adopted is just the first stage of strengthening the integrated sustainable urban development, not only in the cities, but also in their functional urban areas. These are understood as functional territorial units defined by natural ties of interdependences and collabo- 
ration between the city core and peri-urban municipalities, or by collaboration agreements. Hence they can be considered a practical implementation of the principle of multilevel governance in decision-making (LUMAT 2019, p. 9). To get adequate results, it is necessary to invest focused attention in all aspects of development processes and provide long-term support to urban centres and their neighbouring municipalities.

The UDP SR was elaborated as a national framework document, generally defining principles and a set of measures that aim to:

- foster the role of cities in the overall development, emphasising that the term 'urban development' goes beyond the idea of a city or town as a territory that is defined purely by its administrative boundaries;

- motivate territorial governance bodies to improve their performance and monitor the results of the implemented measures;

- promote targeted coordination and the involvement of various representatives so that Slovak cities are run better in the long term, can adapt to new challenges faster and are sustainable, productive and resilient;

- support sharing resources, local capabilities and knowledge as the basis for establishing standard solutions and achieving acceptable and sustainable results;

- highlight the importance of urban development for the overall national development;

- $\quad$ support a more systematic approach to urban development, to identify and involve relevant collaborating advocates and define their tasks in urban development and its governance.

The UDP SR underlines its coherence with the constitutionally established competencies of public administration, including self-government, as well as the need to strengthen the connections between the city or town and its functional territory, between municipalities and self-governing regions, and between urban and rural areas. This should be supported by mechanisms that enable the active engagement of partners from different levels of government, the private sector and the public in the entire cycle of urban development.

The UDP SR addresses both the state administration and self-governmental bodies, focusing on their responsibilities for urban development in the multilevel subsidiary system of territorial governance. The policy itself is embedded into the ongoing reform processes of this system in order to allow synergistic effects in favour of urban development and its better and more efficient governance, including better cross-sectoral coordination that also brings added value to other sectoral policies. The UDP SR determines the essential starting points for further urban development, bringing suggestions as to the main directions and approaches. It has no ambition to be a strategy as this should 
be embodied in a more comprehensive and integrative development strategy with strong contextual interlinks to the regional and local specifics reflected in more targeted and measurable goals. Considering the autonomy in the decision-making of municipal self-governments, this cannot be enforced by state power.

The target groups of the urban policy are the local and regional self-government bodies, mainly focusing on urban municipalities as a special category among municipalities under the Slovak jurisdictional legislation. The document encourages inter-municipal cooperation within functional urban areas. In the case of Slovakia, such collaboration is mainly motivated by a more efficient provision of public services, support for the local economy and employment. Even though rural and urban developments have different parameters, and the outcome always depends on their capacities, they can complement each other. The central premise should be that all advocates are interested in overall prosperity.

As stated in the UDP SR, urban development should be based on the principles of sustainable development, encouraging the combination of economic, social, environmental and cultural targets based on an integrated planning approach.

\subsection{Vision and Principles of National Urban Development as Defined in the UDP SR ${ }^{1}$}

The participatory process of the UDP SR, including representation of the key stakeholders' groups as well as leading professionals in the field of urban and spatial planning, not only allowed the vision of urban development in Slovakia to be shaped, but also proposed generally beneficial and applicable principles and a comprehensive set of measures aspiring to improve conditions for urban development. It led to the establishment of the permanent exchange of information, ideas and opinions useful for sustainable urban development and contributed to the broader public debate on urban development.

The vision brought by this document builds on the complexity of the sustainable urban development concept and the understanding of urban development governance as a permanent process that needs to be undertaken in order to make cities and towns in Slovakia more sustainable and resilient to internal and external turbulences and influences, and provide the conditions for a higher standard of living. 
To secure the sustainable and productive development of cities and towns considering the high level of autonomy of territorial self-governmental bodies, the UDP SR formulates the following vision of urban development in Slovakia:

Urban areas in Slovakia will be managed in such a manner that they will ensure a healthy living environment for a high standard of living through the provision of a diverse range of job opportunities, adequate housing and services as well as environmental protection, and a high quality of urban and architectural solutions. The productivity of Slovak cities and towns will be based on the efficient and sustainable capitalisation of their own resources, and added value generated by their economic base. (Ministry of Transport and Construction of the Slovak Republic 2018b, p. 27, own translation)

To achieve the standards outlined by the vision, the UDP SR formulates three specific principles for sustainable urban development in Slovakia, which should be followed by all representatives in planning and implementing particular urban development strategies:

- Strategic decision-making - based on a responsible utilisation and valorisation of available resources (material, human, financial) with the best possible development of their potential. It will respond to local needs and global trends; planned goals and measures will be hierarchically prioritised and their implementation continuously monitored, evaluated and updated.

- An integrated approach - development will be based on an integrated horizontal (cross-sectoral and economic, social, environmental and cultural) as well as vertical interconnection and cooperation among representatives, including the private and civil sectors.

- Comprehensive development of functional urban areas - development will be based on intensive cooperation beyond administrative boundaries of self-governments, using multilevel governance, mutual coordination of individual activities and measures, and a mutual exchange of information and effective models.

The UDP SR defines the following as the preconditions for achieving the vision of productive cities and towns and providing a healthy environment and a high living standard:

- well-defined municipal responsibilities and funding frameworks;

- good governance including place-based strategies in planning and management of urban areas based on correct data, while still applying an integrated approach;

- strategies focused on creating favourable conditions for the development of a functioning economy while reflecting demographic, environmental and society potentials and challenges and applying the requirements for a good 
quality physical structure and urban environment, including efficient and sustainable urban mobility.

To support progress over the medium term, the UDP SR identifies areas requiring changes and priority tasks, defines deadlines and responsibilities, and frames the cooperation of involved representatives in a more systematic way towards an optimal targeted urban development in Slovakia.

As the main areas of necessary changes, the UDP SR, in line with the above-listed principles and priorities, has identified the following two:

- strengthening the role of urban development in the context of regional development, partnership and cooperation;

- implementing structural changes in city governance.

\subsection{Strengthening the Role of Urban Development in the Context of Regional Development, Partnership and Cooperation}

The UDP SR respects the existing legal environment in which all municipalities, irrespective of their size and nature, or urban or rural character, have the same responsibilities. At the same time, it underlines the challenge of integrating urban development into the comprehensive spatial development, in which cities and towns used to be the cores of functional urban areas as well as the centres of the economic, social and cultural life of the inhabitants of more extensive territories. To balance these two, the UDP SR looks for ways to differentiate the tasks and searches for objective criteria for the transformation of urban development and spatial development policies reflecting them.

An additional challenge addressed within the formulation of the measures is the ongoing processes of decentralisation, which have brought about the need of a better, evidence-based interdependent coordination of sectoral policies and approaches while avoiding the frequent contradictions of a sectoral approach as applied by various ministries and strategic or conceptual documents. The UDP SR not only underlines the role of cross-sectoral strategies, but also the necessity of an interdisciplinary and multidimensional approach for the proper projection of dynamic social and economic development in the urban environment. The UDP SR expresses the ambition to engage in the ongoing processes of improving state management, aiming at extending the intervention logic of strategic planning across the central state administration bodies and self-governmental bodies, especially focusing on interdependences between responsibilities and resource management, including the public financing system. 
Under the complex task of 'strengthening the role of urban development in the context of regional development, partnership and cooperation', the UDP SR defines the following measures:

- Prepare an overview of the services provided by municipal authorities, local state administration and self-governing regions with an emphasis on their interconnection and cooperation. Part of the outline will focus on the capital city of Bratislava and the city of Košice (the second largest city in Slovakia), with an emphasis on their location and the relationships with the city districts;

- Participate actively in the process of implementing the strategic planning and management system in the state administration and to support the synergies between state policies and the strategic objectives of territorial self-government, while also securing support for urban development within the framework of the National Infrastructure Plan;

- Establish a 'Platform for the Development of Slovak Cities and Towns', with the main aim of providing for a professional discussion on the principles and practical applications of integrated urban development and management;

- Link different existing platforms, providing access to information, support tools and examples of best practice in urban development;

- Elaborate pilot analysis of the existing cooperation of a selected range of urban settlements and their surroundings (functional urban areas) and explore positive externalities coming from such a cooperation model for municipalities and inhabitants in the given territory, with the possibility of proposing the modification of the existing structure and relations within the area;

- Support the formation and development of territorial cooperative structures consisting of urban municipalities and their neighbouring municipalities and the preparation of joint integrated planning and strategic documents;

- Integrate urban development into the regional development strategy as a component of regional and territorial development policy, including the identification of specific objectives and tools to support the development of cities, towns and functional urban areas;

- Include support for the sustainable integrated development of cities, towns and functional urban areas among the national priorities in negotiations on the future EU Cohesion Policy. 


\subsection{Implementing Structural Changes in City and Town Governance}

Another difficult task defined by the UDP SR focuses on structural changes in the functioning of cities and towns. As a crucial framework for evidence-based and place-based urban policies that safeguard sustainable development, the UDP SR can monitor the permanent process of systematic monitoring and analyse the related processes, allowing early identification of trends and problems. That is because the measures associated with this complex task specifically address information and statistical data collection and management. The ongoing reform of the statistical data collection system in Slovakia presents a good opportunity to improve the quality of data necessary for a sustainable urban development management plan and aims to optimise processes and introduce a new methodological framework and IT tools, as well as reduce the administrative burden on citizens and public and private agencies.

The UDP SR pays attention to the task of strengthening and better balancing the system of multi-source and hybrid financing of urban development, anticipating a drop in the funding of development projects by the European Structural and Cohesion Funds. This task is understood as complementary to the improvement of the efficiency of public spending.

An important aspect of the development of Slovak urban areas addressed by the UDP SR is the threat of increasing social inequality and spatial segregation based on the social status of individuals and groups of the population. The policy identifies promotion of a social mix as one of the best answers to this problem, along with applying the principles of integrated design, urban regeneration and the strengthening of civil society. In this regard, the measures focused on regeneration of unused, abandoned or neglected areas within the built-up areas have a high potential to contribute to their improvement (Jamečný and Husár 2016), in addition to being important in preventing urban sprawl and in intensifying inner-city structures.

In accordance with the UDP SR, structural changes in urban systems need to reflect the challenge of global climate change with its negative impacts on the urban environment - or in more specific terms buildings; social, technical and transport infrastructures; public spaces; water management and greenery or green infrastructure; population health - and also economic activities, especially agriculture and forestry.

The UDP SR stresses the effects of climate change on increased consumption of energy for cooling in urbanised environments, which will increase the demands for energy infrastructure, including safe, sustainable and reliable energy production and distribution. The policy applies a systemic approach to adaptation to climate change as a crucial task for urban authorities, which must be taken into account at the very early stage of urban planning regula- 
tion. Plans and building permissions need to be based on a careful evaluation of area vulnerability and the identification of the potential risks and consequences of climate change in all critical areas as a precondition of proposing and implementing effective adaptation measures in urban environments and communities.

Measures linked to the structural changes in the city and town governance are defined by the UDP SR as follows:

- Assess the availability of existing data needed for urban development and, if necessary, expand, adjust or modify sets of data collected by the National Statistical System and other sources;

- Analyse the possibility of introducing a pilot support tool to fund urban development and analyse the opportunities of expanding support from the State Housing Development Fund for revolving financing of projects in the area of urban development;

- Analyse obstacles to re-using and revitalising the unused, abandoned and neglected regions in urban areas and propose support measures;

- Promote the improvement of urban accessibility by increasing the take-up of public passenger transport (rail, buses, sharing mobility) and by promoting non-motorised transport, building cycling routes and other cycling infrastructure;

- Encourage urban authorities to adapt to the adverse impacts of climate change and support inclusion of adaptation measures in urban planning;

- Promote biodiversity protection in urban areas and their surroundings (protecting and creating green infrastructure, combining the activities of protecting biodiversity and ensuring human health, etc.).

\section{DRIVING FORCES OF THE CHANGES IN URBAN DEVELOPMENT POLICY}

As declared in the UDP SR, the new urban policy has been understood and elaborated as a national governance tool reflecting the need to react to current challenges and problems in urban development in Slovakia. Critical analysis of existing policies linked to urban development and of their effects falling short of expectations showed the necessity of covering the issues of urban development through a profiled urban policy (Government Office of the Slovak Republic 2018). Still, a stronger relationship with other comprehensive and sectoral policies, represented, first of all, by the Spatial Development Perspective of Slovakia and by the National Regional Development Strategy, is necessary. Moreover, the increasing dynamics of changes in urban development and urban socio-ecosystems' functioning required a new policy based on innovative approaches, applied across the whole hierarchic system of 
urban governance, able to deal with forthcoming development disparities and regional and local specifics.

Although the turbulent and very dynamic urban development determined by far-reaching changes and transformation processes in the Slovak economy and society after 1989 was more or less successfully framed by the continuity of a comprehensive planning system, the new quality achieved by the settlement system requires an adequate response in urban development policy across all levels of governance. The UDP SR is opening the way to it.

As this new quality is a by-product of economic and societal development, the key driving forces of the changes in urban development policy are directly linked to the key players of crucial development processes - the transformation from an industrial towards a post-industrial market economy and from post-socialistic representative democracy towards an active civil society. The combination of these two main development trajectories brought the 'fuzzification' and softening of the separation of different levels of governance structures and their territorial division, the multiplication of urban development actors, increased spatial effects of their individual decisions, and the regionalisation of both local policies and state policies. Urban development policy - determined by intensive interplay between all hierarchical levels, within different temporal dimensions, between public and private representatives - became less and less the policy of public bodies and more and more a joint policy of various urban development advocates, in which public sector representatives are more diverse, reaching far beyond the governmental and self-governmental bodies.

Although being limited in their operational space by strong economic interests, diverse interests expressed by the wider public and contradictions between available resources and responsibilities for safeguarding societal values and sustainability, the representatives of the public sector play a specific role in urban development management. In the context of the development of a knowledge-based economy, the quadruple helix (universities-industrygovernment-civil society), directly linked to urban environment and its territorial organisation, became a significant concept not only in productive sectors but also in the service sector (Zajko and Brighton 2015). The driving forces of the development and implementation of smart specialisation concepts in urban development in Slovakia are clusters using this concept of innovation-oriented partnership, allowing, in addition, the solution of the problem of the limited professional capacities of public administration. Implementation of smart development concepts including smart governance in Slovak cities brought growing engagement of citizens in the numerous NGOs and private sector representatives and their involvement not only in the decision-making processes, but in the realisation of projects implementing public development strategies. As the COVID-19 crisis has confirmed, the engagement of NGOs 
and the private sector is not limited to their role as players in formulating and implementing urban development strategies (as described by Schöffel et al. 2014), but also extends to crisis management. People are more empowered as a result of better participation and inclusion in governance processes and thanks to the self-realisation of their power to directly affect decision-making. The hierarchic territorial system of governing public bodies as the leading actors in decision-making is going to be transformed into a system of polycentric multilevel governance based on multi-actor decision-making processes. This process has already been running within the preparatory phase of the next EU programming period 2021/2027 and will be supported by the institutional reform as planned in the Programme Declaration of the Slovak Government for 2020/2024 (Government of the Slovak Republic 2020) and The National Reform Programme of the Slovak Republic 2019 (Ministry of Finance of the Slovak Republic 2019).

\section{CONCLUSIONS}

The Urban Development Policy of the Slovak Republic by 2030 is the first national conceptual document that directly addresses urban development matters at the national level. This document, in the form of a concept without an ambition to become a strategy, is the result of searching for a compromise between firm embeddedness of the comprehensive spatial development strategies reflecting strong urban-rural ties and the need to articulate specific principles for urban development policy in reaction to specific problems and challenges. The UDP SR was developed and has been implemented via a continuously evolving multilevel polycentric governance system, using its proximity to the citizens to be more efficient in addressing regional and local specifics using capacities across the full spectrum of urban development advocates. The preparatory process of the UDP SR was positively influenced, and to a certain extent motivated, by the active involvement of the Slovak representatives in the preparation of the HABITAT III New Urban Agenda adopted in Quito in 2016. These experts directly participated in the development of the UDP SR, taking lead positions in the process. The New Urban Agenda of the United Nations along with the New Urban Agenda for the EU, both adopted by the Slovak government, created an important political framework that paved the way to the adoption of the UDP SR.

The implementation of the UDP SR as adopted is just the first stage of strengthening integrated sustainable urban development in cities, towns and their functional urban areas in Slovakia and beyond the national border. To get solid results it is necessary to activate communities and urban development advocates to carry out concentrated actions focused on urban transformation. There is the need for a more sustainable and more resilient urban environment 
and to provide long-term support to the activities of cities across all levels of the governance system. The cities and towns in Slovakia, being directly involved in the process of UDP SR definition, welcomed the fact that for the first time urban policy in Slovakia is covered by a comprehensive conceptual document. Nevertheless, they accept with criticism the fact that the document does not have any ambition to introduce financial implementation tools. This critical point is going to be addressed by the new integrative approaches to regional and urban development support (integrated territorial strategies and integrated territorial investments at the regional level and the level of functional urban areas with their core cities and towns) that are already in the preparatory phase for the new programming period 2021/27 and in a new act on regional development expected in 2021. The need for new urban development policies and new approaches in urban governance has been clearly noticed during the COVID-19 crisis, and in accordance with political declarations will be mirrored in the distribution of post-Covid revival and transition financial support.

\section{NOTE}

1. The Urban Development Policy of the Slovak Republic by 2030 (Koncepcia mestského rozvoja Slovenskej Republiky do 2030) was prepared by the Ministry of Transport and Construction of the Slovak Republic in 2018. The document is available at https:/www.mindop.sk/uploads/media/dc4765f0d $90557 \mathrm{fb} 2 \mathrm{f} 4 \mathrm{e}$ eeed9bdf13c78f58f128.pdf.

\section{REFERENCES}

Act no. 221/1996 Coll. on Territorial and Administrative Division of the Slovak Republic, as amended.

Act no. 302/2001 Coll. on Self-Government of Regions, as amended.

Act no. 369/1990 Coll. on Municipalities, as amended.

Act no. 416/2001 Coll. on Decentralization and Transition of Competences from the State Government Bodies to Self-Government Bodies at Regional and Local Levels, as amended.

Committee of Regions (2014), Charter for Multilevel Governance in Europe, accessed 30 May 2020 at https://portal.cor.europa.eu/mlgcharter/Pages/MLG-charter.aspx.

Committee of Regions (2020), Charter for Multilevel Governance (MLG) in Europe, accessed 30 May 2020 at https://portal.cor.europa.eu/mlgcharter/Pages/default.aspx.

Dijkstra, L. and H. Poelman (2012), Cities in Europe: The New OECD-EC Definition. Regional Focus, 1/2012. European Commission, accessed 27 January 2021 at https:// ec.europa.eu/regional_policy/sources/docgener/focus/2012_01_city.pdf.

Faragó, L. and K. Varró (2016), 'Shifts in EU Cohesion Policy and processes of peripheralization: A view from Central Eastern Europe', European Spatial Research and Policy, 23 (1), 5-19.

Finka, M. (2002), Urban Society and Economy: Achieving Social Equity through Effective Planning Policies and Tools. National Report for UNECE 2002. 
Finka, M. and T. Kluvánková (2015), 'Managing complexity of urban systems: A polycentric approach', Land Use Policy, 42, 602-608.

Finka, M., T. Kluvánková and V. Ondrejička (2015), 'Concept of polycentric governance for fuzzy soft spaces as a challenge for Central European peripheral spaces', in T. Lang, S. Henn, W. Sgibnev and K. Ehrlich (eds), Understanding Geographies of Polarization and Peripheralization. Basingstoke, UK: Palgrave Macmillan, pp. 309-322.

Government Office of the Slovak Republic (2018), Úvodná správa k národnej stratégii regionálneho rozvoja [Introductory Report to the National Strategy of the Regional Development].

Government of the Slovak Republic (2020), Programme Declaration of the Slovak Government for 2020/2024 [Programové vyhlásenie vlády Slovenskej republiky na obdobie rokov 2020-2024] accessed 8 June 2020 at http://mepoforum.sk/wp -content/uploads/2020/04/V1\%C3\%A1da-SR-Programove-Vyhlasenie-2020-2024 .pdf.

Hooghe, L. and G. Marks (2003), 'Unraveling the central state, but how? Types of multi-level governance', American Political Science Review, 97, 233-234.

Iammarino, S., A. Rodríguez-Pose and M. Storper (2017), 'Why regional development matters for Europe's economic future', Working Paper 7 of the European Commission Directorate General for Regional and Urban Policy.

Jamečný, L. and M. Husár (2016), 'From planning to smart management of historic industrial brownfield', paper presented at World Multidisciplinary Civil Engineering-Architecture-Urban Planning Symposium 2016, Prague: WMCAUS 2016.

Jaššo, M. and D. Petríková (2016), 'Place attachment and social communities in the concept of smart cities', in A. Leon-Garcia et al. (eds), Smart City $360^{\circ}$. SmartCity 360 2016, SmartCity 360 2015. Lecture Notes of the Institute for Computer Sciences, Social Informatics and Telecommunications Engineering. Cham: Springer, pp. 721-728.

Jordan, A. (2008), 'The governance of sustainable development: Taking stock and looking forwards', Environment and Planning C: Government and Policy, 26 (1), $17-33$.

Lang, T. (2015), 'Socio-economic and political responses to regional polarisation and socio-spatial peripheralisation in Central and Eastern Europe: A research agenda', Hungarian Geographical Bulletin, 64 (3), 171-185.

Lang, T. and F. Görmar (eds) (2019), Regional and Local Development in Times of Polarisation: Re-thinking Spatial Policies in Europe. Springer Nature.

LUMAT (2019), LUMAT Project Booklet Implementation of Sustainable Land Use in Integrated Environmental Management of Functional Urban Areas, accessed 30 May 2020 at https://www.interreg-central.eu/Content.Node/LUMAT/Final-Booklet .pdf.

McGinnis, M. D. (1999), Polycentric Governance and Development: Readings from the Workshop in Political Theory and Policy Analysis. University of Michigan Press.

Ministry of Finance of the Slovak Republic (2019), The National Reform Programme of the Slovak Republic 2019 [Národný program reforiem Slovenskej republiky 2019], accessed 8 June 2020 at https://www.finance.gov.sk/files/en/finance/institute -financial-policy/strategic-documents/national-reform-program/npr-2019 final-en.

Ministry of Transportation and Construction of the Slovak Republic (2018a), Report on the Fulfilment of the Intentions of the Concept of the State Housing Policy until 
2020 (in Slovak), accessed 11 June 2020 at https://www.mindop.sk/sprava-o-plneni -zamerov-koncepcie-statnej-bytovej-politiky-do-roku-2020.

Ministry of Transport and Construction of the Slovak Republic (2018b), Urban Development Policy of the Slovak Republic by 2030, accessed 8 June 2020 at https:// www.mindop.sk/uploads/media/dc4765f0d90557fb2f4eeeed9bdf13c78f58f128.pdf.

OECD (2005), The Measurement of Scientific and Technological Activities: Guidelines for Collecting and Interpreting Innovation Data: Oslo Manual, Third Edition, prepared by the Working Party of National Experts on Scientific and Technology Indicators. Paris: OECD.

OECD (2019), OECD Development Co-operation Peer Reviews Slovak Republic 2019, accessed 2 January 2019 at https://www.oecd.org/dac/oecd-development-co -operation-peer-reviews-slovak-republic-2019-9789264312326-en.htm.

Ondrejička, V. and M. Finka (2016), 'Innovative approaches to strategic socioeconomic planning of territorial subjects', Vysoka Skola Ekonomicka v Praze, Praha, pp. 176-188.

Ostrom, V., C. M. Tiebout and R. Warren (1961), 'The organization of government in metropolitan areas: A theoretical inquiry', American Political Science Review, 55 (4), 831-842.

Rosenau, J. N. (1997), Along the Domestic-Foreign Frontier: Exploring Governance in a Turbulent World. Cambridge: Cambridge University Press.

Schakel, A. H. (2016), 'Applying multilevel governance', in H. Keman and J. J. Woldendorp (eds), Handbook of Research Methods and Applications in Political Science. Cheltenham, UK and Northampton, MA, USA: Edward Elgar Publishing, pp. 97-110.

Schöffel, J., M. Finka and V. Ondrejička, (eds) (2014), Participative Planning in Planning Culture of Slovak Republic. Rapperswil: IRAP.

Schulz, S. (2019), 'Ambitious or ambiguous? The implications of smart specialisation for core-periphery relations in Estonia and Slovakia', Baltic Journal of European Studies, 9 (4), 49-71.

Statistical Office of the Slovak Republic (2020), Size Groups of Municipalities, accessed 28 May 2020 at http://statdat.statistics.sk/cognosext/cgi-bin/cognos .cgi?b_action $=$ cognosViewer\&ui.action=run\&ui.object=storeID $\% 28 \% 22 \mathrm{i} 0 \mathrm{C}$ 852CĀA5451437C92774DB33EC08675\%22\%29\&ui.name=Ve\%C4\%BEkostn \%C3\%A9\%20skupiny\%20obc\%C3\%AD\%20\%20SR\%2C\%20oblasti\%2C $\% 20 \mathrm{kraje} \% 2 \mathrm{C} \% 20$ okresy\%2C\%20mesto\%2C\%20vidiek\%20\%5Bom7023rr $\% 5$ D\&run.outputFormat $=\&$ run.prompt $=$ true \&cv.header $=$ false \&ui.backURL $=\% 2$ Fcognosext $\% 2$ Fcps $4 \% 2$ Fportlets $\% 2$ Fcommon $\% 2$ Fclose.html\&run .outputLocale $=$ sk.

Zajko, M. and D. Brighton (2015), 'Conceptual frameworks for higher education institution and industry collaboration', in D. Brighton, M. Zajko and K. Pezoldt (eds), Successful Innovations? Efficient Knowledge and Technology Transfer and International Collaboration. Ilmenau: Universitätsverlag Ilmenau, pp. 11-76. 